\title{
NOTES
}

\section{Effect of Acylation on Peptide Synthesis by Immobilized Thermolysin}

\author{
Shigeru KUnUGI, ${ }^{*}$ Yoshio MoriKawa, Toshihiro KondOH, \\ and Akihiko NomURA \\ Department of Applied Chemistry, Fukui University, \\ Bunkyo, Fukui 910, Japan
}

(Received April 25, 1988)

\begin{abstract}
KEY WORDS Immobilized Enzyme / Thermolysin / Acylation / Chemical Modification / Peptide Synthesis /
\end{abstract}

A natural enzyme often shows strict specificity so that it is hard to use for a reaction of less specific substrates. Modulation of the enzyme function through structure, by either genetic or chemical procedure may eliminate this difficulty. A number of studies on chemical modification of enzyme has been performed to elucidate the detailed reaction mechanism and the results are very interesting for practical use of enzyme reactions. One example is the peptide formation catalyzed by a proteolytic enzyme. Here we take thermolysin, a thermostable neutral protease from $B$. thermoproteoliticus, ${ }^{1}$ as the target. This enzyme can catalyze a condensation of $N$-acylamino acid and amino acid amide (eq 1: AC, acylgroup; $\mathrm{AA}$ and $\mathrm{AA}^{\prime}$, amino acid residue). ${ }^{2}$

$\mathrm{AC}-\mathrm{AA}+\mathrm{AA}^{\prime}-\mathrm{NH}_{2} \rightarrow \mathrm{AC}-\mathrm{AA}-\mathrm{AA}^{\prime}-\mathrm{NH}_{2}(1)$

We have investigated several kinetic aspects of free and immobilized thermolysin. ${ }^{3,4}$ On the mechanism of this enzyme Vallee's school reported extensive studies ${ }^{5-7}$ and showed that this enzyme exhibits different catalytic behavior when the active site zinc ion is replaced by cobalt ion ${ }^{7}$ or when Tyr-110 was acylated with $N$-acetylamino acid. ${ }^{6}$ The latter result

\footnotetext{
* To whom all correspondence should be addressed.
}

was further certified by another independent group. ${ }^{8}$ Though a peptide condensation reaction is the reverse reaction of hydrolysis, there are many factors controlling the rate and yield and therefore the effect of chemical modification on the condensation reaction cannot be estimated straightforward from the results of hydrolytic reactions.

Recently, studies on the effect of metal substitution of thermolysin on the peptide synthesis were reported for the free (soluble) and immobilized states of an enzyme. ${ }^{9,10}$ Here we examine the effect of acylation on a few simple condensation reactions catalyzed by thermolysin immobilized on glass matrices. The immobilized state is chosen for ease of various chemical treatments and feasibility of applications. Since immobilization of an enzyme is already a "chemical" modification, this example is a sort of double modification.

\section{EXPERIMENTAL}

Thermolysin (donated by Daiwa Kasei Co., Ltd., Osaka, Japan; Lot T4KB31, 32) was immobilized on porous glass beads (FPG700S; 200-400 mesh, Wako Pure Chemicals, 
Osaka, Japan) by the method of Kousaka ${ }^{11}$ using $\gamma$-aminopropyltriethoxysilane (Tokyo Kasei, Tokyo, Japan) as a pendant and glutaraldehyde as a linker. ${ }^{12}$ The immobilization yield was estimated from the UV absorption of the washing eluent to be about $55 \%$ of the initial amount of the enzyme. Thus immobilized thermolysin (Im-TLN) was acylated by $N$-acetylamino acid $N$-hydroxysuccinimide ester $(\mathrm{Ac}-\mathrm{Xxx}-\mathrm{OSu} ; \mathrm{Xxx}=\mathrm{Phe}$ or Ala) essentially following the method of Blumberg et al. for the soluble enzyme. ${ }^{6} \quad N-[3-(2-$ Furyl)acryloyl]dipeptide amide was used in the hydrolytic study after our previous kinetic studies on the soluble enzyme ${ }^{3-5}$ and hence a combination of $\mathrm{N}$-([3-(2-furyl)acryloyl]amino acid (Fua-Xxx) and amino acid amide was chosen for the condensation reaction. Immobilized enzyme was assayed by analyzing a portion of reaction mixture taken at intervals on HPLC (Shimadzu LC6A-Cosmosil 5C18P) after quenching by mixing with an excess volume of acetonitrile and $5 \%$-aqueous phosphoric acid. Activities were expressed in terms of $\%$ substrate hydrolyzed after the indicated time with $10 \mathrm{mg}$ (wet) of Im-TLN placed in $1 \mathrm{ml}$ of solution for the hydrolysis reaction. The condensation reaction was carried out in $75(\mathrm{v} / \mathrm{v}) \%$ acetonitrile with amino acid amide in excess. The result is expressed in terms of the obtained amount of product relative to the initially given amount of the acyl moiety.

\section{RESULTS AND DISCUSSION}

Table I shows the influence of acylation on the hydrolysis of some dipeptide substrates. The Ac-Phe-acylated Im-TLN showed higher hydrolytic activity on Fua-Gly-Phe- $\mathrm{NH}_{2}$ and Fua-Gly-Leu- $\mathrm{NH}_{2}$ than the control. On the contrary, the Ac-Phe-acylated enzyme showed a considerably smaller hydrolytic rate on FuaPhe--Phe- $\mathrm{NH}_{2}$ and Fua-Phe-Leu-NH $\mathrm{NH}_{2}$. For the free thermolysin, the acylation with $\mathrm{N}-\mathrm{Ac}-$ Phe-OSu was reported to show an acceleration of the hydrolysis of Fua-Gly-Leu- $\mathrm{NH}_{2}$ over
Table I. Effect of acylation on peptide hydrolysis by immobilized TLN

\begin{tabular}{|c|c|c|c|}
\hline \multirow{2}{*}{ Substrate } & \multicolumn{2}{|c|}{ Hydrolyzed amount ${ }^{\mathrm{a}}$} & \multirow{2}{*}{$k_{\mathrm{A}}^{\mathrm{b}}$} \\
\hline & Control & Ac-Phe-Im-TLN & \\
\hline Fua-Gly-Leu- $\mathrm{NH}_{2}$ & 11 & 36 & 1.9 \\
\hline Fua-Gly-Phe-- $\mathrm{NH}_{2}$ & 12 & 39 & 2.1 \\
\hline Fua-Phe-Leu- $\mathrm{NH}_{2}$ & 43 & 4.6 & 32 \\
\hline Fua-Phe-Phe- $\mathrm{NH}_{2}$ & 37 & 7.4 & 37 \\
\hline
\end{tabular}

a Amount ( $\%$ ) of hydrolyzed substrate after $1 \mathrm{~min}$ in-

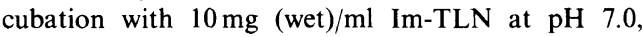
$37^{\circ} \mathrm{C}$. [substrate] $=1 \mathrm{mM}$.

b Second-order rate constant of the hydrolysis by free enzyme (at pH $6.5,25^{\circ} \mathrm{C}$, in $10^{4} \mathrm{M}^{-1} \mathrm{~s}^{-1}$ ) to show the specificity of each substrate.

Table II. Effect of acylation on peptide condensation catalyzed by immobilized TLN

\begin{tabular}{|c|c|c|c|}
\hline \multirow{2}{*}{ Substrate } & \multicolumn{3}{|c|}{ Product yield $(\%)^{\mathrm{a}}$} \\
\hline & Control & Ac-Phe- & Ac-Ala- \\
\hline Fua-Gly + Leu- $\mathrm{NH}_{2}$ & 19 & 40 & 18 \\
\hline Fua-Gly + Phe $-\mathrm{NH}_{2}$ & 6.9 & 16 & 5.5 \\
\hline Fua-Phe + Leu- $\mathrm{NH}_{2}$ & 73 & 77 & 77 \\
\hline Fua $-\mathrm{Phe}+\mathrm{Phe}-\mathrm{NH}_{2}$ & 57 & 61 & 57 \\
\hline
\end{tabular}

a Product $(\%)$ observed after $6 \mathrm{~h}$ incubation of $1 \mathrm{mM}$ acyl moiety with $20 \mathrm{mM}$ amino part and $10 \mathrm{mg}$ (wet) $/ \mathrm{ml} \mathrm{Im-TLN}$ at $\mathrm{pH} 7.0,37^{\circ} \mathrm{C}$.

20 fold, ${ }^{6}$ which is larger than the present case. This might be caused by a possible difference in the efficiency of the acylation reaction and the present discrete method of the observing the hydrolytic reaction.

The modified Im-TLN showed peptide synthetic ability as summarized in Table II. In the case of the smaller acyl moiety (Fua-Gly) AcPhe-acylated Im-TLN showed higher yield than the control while practically no influence of the acylation was observed with the larger acyl moiety (Fua-Phe). Acylation with Ala derivative gave similar results with the native one.

The acylation site of thermolysin by AcPhe-OSu was estimated as Tyr- $110,{ }^{6}$ which was located on the side wall of the substrate bind- 
ing site. ${ }^{13}$ The introduction of a large side chain by acylation with Phe derivative may increase the interaction between the binding site and the substrate of smaller side chain to make it fixed in a preferable geometry for the hydrolytic reaction. On the other hand, it hinders the incorporation of a rather large amino acid side group such as Phe and Leu to make it unfavorable for the reaction. In the case of a peptide condensation reaction catalyzed by Im-TLN, the interaction of the acyl part of the substrate of smaller side chain with Phe-group attached on the enzyme may be preferable for the peptide condensation and increase the yield. However, hindrance to large acyl components is apparently less than that for hydrolysis. This is related to the fact that the peptide condensation reaction by this enzyme is largely equilibrium-controlled for a combination of specific substrates. ${ }^{2}$ It is noted that the modified Im-TLN has catalytic activity for the condensation reaction of specific substrates comparable to the native one and the effect of modification is only an increase in activity for the condensation of less specific substrates, i.e., to broaden substrate specificity.

\section{REFERENCES}

1. S. Endo, J. Ferment. Technol., 40, 346 (1962); S. A. Latt, B. Holmquist, and B. L. Vallee, Biochem. Biophys. Res. Commun., 37, 333 (1969); H. Matsubara, Methods Enzymol., 19, 642 (1970).

2. Y. Isowa, M. Ohmori, T. Ichikawa, K. Mori, Y. Nonaka, K. Kihara, K. Oyama, H. Satoh, and S. Nishimura, Tetrahedron Lett., 28, 2611 (1979); K. Oyama, K. Kihara, and Y. Nonaka, J. Chem. Soc.,
Perkin Trans. 2, 356 (1981); K. Oyama, S. Nishimura, Y. Nonaka, K. Kihara, and T. Hashimoto, J. Org. Chem., 46, 5242 (1981); K. Nakanishi, T. Kamikubo, and R. Matsuno, Bio/ Technology, 3, 459 (1985); T. Oka and K. Morihara, J. Biochem., 88, 807 (1980); S. I. Wayne and J. S. Fruton, Proc. Natl. Acad. Sci. U.S.A., 80, 3241 (1983).

3. S. Kunugi, H. Hirohara, and N. Ise, Eur. J. Biochem., 124, 157 (1982); M. Fukuda and S. Kunugi, Bull. Chem. Soc. Jpn., 57, 2965 (1984); M. Fukuda and S. Kunugi, Eur. J. Biochem., 142, 565 (1984).

4. S. Kunugi, Y. Morikawa, M. Ishida, and Y. Nakamura, Polym. J., 19, 269 (1987).

5. S. A. Latt, B. Holmquist, and B. L. Vallee, Biochem. Biophys. Res. Commun., 37, 333 (1969); T. A. Kaden, B. Holmquist, and B. L. Vallee, ibid., 46, 1654 (1972); F. S. Kennedy, H. A. O. Hill, T. A. Kaden, and B. L. Vallee, ibid., 48, 1533 (1972); B. Holmquist, T. A. Kaden, and B. L. Vallee, Biochemistry, 14, 1454 (1975).

6. S. Blumberg, B. Holmquist, and B. L. Vallee, Biochem. Biophys. Res. Commun., 51, 987 (1973); S. Blumberg, B. Holmquist, and B. L. Vallee, Isr. J. Chem., 12, 643 (1974); S. Blumberg and B. L. Vallee, Biochemistry, 14, 2410 (1975); S. Blumberg, ibid., 18, 2815 (1979).

7. B. Holmquist and B. L. Vallee, J. Biol. Chem., 249, 4601 (1974); H. Barton and B. L. Vallee, Biochemistry, 15, 101 (1976).

8. J. Riikoja, N. Paberit, M. Pank, and A. Aaviksaar, Eesti NSV Tead. Akad. Toim. Keem., 33, 257 (1984) (Chem. Abst., 102, 74635g).

9. I. Durrant, R. J. Beynon, and P. B. Rodgers, Trans. Biochem. Soc., 14, 957 (1986).

10. Y. Morikawa, T. Kondoh, and S. Kunugi, Abstract of Papers, 53th Annual Meeting of the Chemical Society, Japan, 1986, p 711.

11. A. Kousaka, Rinshoukensa, 22, 1186 (1978).

12. S. Kunugi, Y. Morikawa, and A. Nomura, Mem. Fac. Eng., Fukui Univ., 36, 45 (1988).

13. P. M. Colman, J. N. Jansonius, and B. W. Matthews, J. Mol. Biol., 70, 701 (1972). 